Western University

Scholarship@Western

Aboriginal Policy Research Consortium International (APRCi)

2007

\title{
Planning for aboriginal communities in Western Austalia
}

Ashley Randell

Follow this and additional works at: https://ir.lib.uwo.ca/aprci

Part of the Public Administration Commons, and the Urban Studies Commons

Citation of this paper:

Randell, Ashley, "Planning for aboriginal communities in Western Austalia" (2007). Aboriginal Policy Research Consortium International (APRCi). 353.

https://ir.lib.uwo.ca/aprci/353 
This article was downloaded by: [University of Western Ontario]

On: 01 December 2012, At: 07:48

Publisher: Routledge

Informa Ltd Registered in England and Wales Registered Number: 1072954 Registered office: Mortimer House, 37-41 Mortimer Street, London W1T 3J H, UK

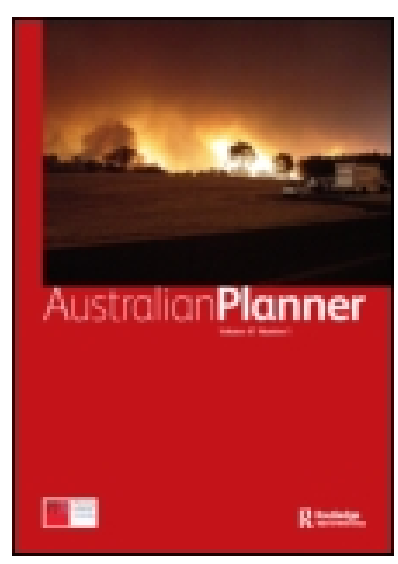

\title{
Australian Planner
}

Publication details, including instructions for authors and subscription information: http:// www.tandfonline.com/loi/ rapl20

\section{Planning for aboriginal communities in Western Austalia}

\author{
Ashley Randell ${ }^{\text {a }}$ \\ ${ }^{a}$ Team Leader, Planning for Aboriginal Communities Project \\ Version of record first published: 22 Dec 2010.
}

To cite this article: Ashley Randell (2007): Planning for aboriginal communities in Western Austalia, Australian Planner, $44: 4,8-9$

To link to this article: http:// dx. doi. org/ 10.1080/07293682.2007.9982602

\section{PLEASE SCROLL DOWN FOR ARTICLE}

Full terms and conditions of use: http://www.tandfonline.com/page/terms-and-conditions

This article may be used for research, teaching, and private study purposes. Any substantial or systematic reproduction, redistribution, reselling, loan, sub-licensing, systematic supply, or distribution in any form to anyone is expressly forbidden.

The publisher does not give any warranty express or implied or make any representation that the contents will be complete or accurate or up to date. The accuracy of any instructions, formulae, and drug doses should be independently verified with primary sources. The publisher shall not be liable for any loss, actions, claims, proceedings, demand, or costs or damages whatsoever or howsoever caused arising directly or indirectly in connection with or arising out of the use of this material. 


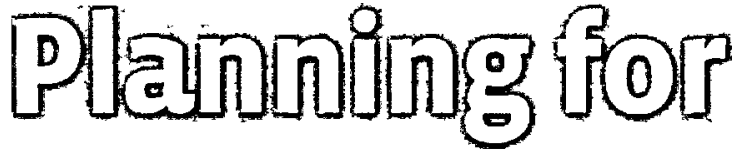

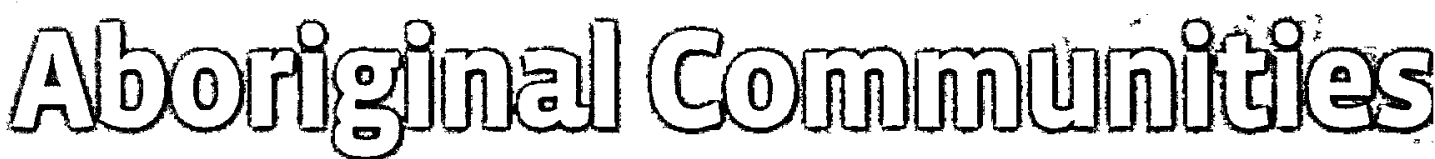

in Wesitern Alusitrallia

Author: Ashley Randell

Team Leader, Planning for Aborıinal Communities Project

\section{Aboriginal Communities in WA}

There are more than 280 discrete Aboriginal communities in Western Australıa, accommodating some 17,000 people. Eighty per cent of the residents of these communities live in approximately 80 large, permanent communities that support populations of between 50 and 800 people.

Development in Aboriginal communities has historically occurred outside normal statutory regimes, and as a result, people living in Aboriginal communities have not enjoyed the standard of living most Western Australians take for granted.

\section{Western Australian Planning Commission}

The Western Australian Planning Commission (WAPC) is the statutory authority with statewide responsibilities for urban, rural and regional land use planning and land development matters. The WAPC responds to the strategic direction of government and is responsible for the strategic planning of the state.

The WAPC operates with the support of the Department for Planning and Infrastructure (DPI), which provides professional and technical expertise, administrative services, and resources to advise the WAPC and implement its decisions. In this partnership the WAPC has responsibility for decision-making and a significant level of funding while the department provides the human resources and professional advice

\section{State Planning Policy No.3.2}

State planning policies are prepared and adopted by the WAPC under statutory procedures set out in part 3 of the Planning and Development Act 2005 The process of preparing a state planning policy also includes public consultation and consideration by the Minister for Planning and the Governor.

The WAPC and local governments must have 'due regard' to the provisions of state planning policies when preparing or amending local planning schemes and when making decisions on planning matters.

State Planning Policy No $32-$ Planning for Aboriginal Communities provides a framework for the planning of large permanent Aboriginal communities in WA. The objectives of this policy are to improve the standard of living and quality of life of people living in Aboriginal communities by:

" providing a framework to ensure that large permanent Aborigina! communities are afforded a high level of service;

" ensuring that these communities and associated land uses are appropriately identified and zoned within town planning schemes; and

" providing a mechanism that will enable both local government and the WAPC to approve community layout plans.

\section{Planning for Aboriginal Communities Project}

The WAPC has run the Planning for Aboriginal Communities Project in its current form since 2002. The project aims to implement State Planning Policy 32 through the preparation and endorsement of community layout plans

Community Layout Plans (CLPS) are basically mini town plans that are approved by Aborigınal community councils, local governments and the WAPC. Over 80 CLPs have been approved since 2000 and more than 30 plans are currently underway

\section{Community Layout Plans}

Community Layout Plans are developed in close consultation with communities, represent the aspirations of the residents and provide a basis for future housing and infrastructure programs. This is ending the ad hoc approach to development that has characterised construction in Aboriginal communities for many years

The Planning for Aboriginal Communities Project enjoys a high level of support and collaboration between state and local governments, the private sector and Aboriginal communities.

CLPs are plans prepared in-house and also by consultants. Determining priorities for preparation of CLPs occurs in consultation with the Department of Housing and Works through the Aboriginal Housıng and Infrastructure Council.

The main benefit of CLPs is to bring to communities the services and facilities that people in WA take for granted, such as protection of drinking water source, separation from noisy, toxic or hazardous activities, sealed roads, serviced housing lots and adequate drainage.

Communities are also able to use their CLPs to negotiate with developers when housing or construction is due to take place in their community. The Aboriginal Lands Trust (ALT) has resolved that all development on ALT land should conform with community layout plans, and has introduced a Land Use and Development Policy to that end.

CLPs have also proven to be a useful vehicle for tenure reform and rearrangement on Aboriginal communities. This can include recommendation to the ALT to transfer land from its estate to the incorporated body that runs a community and recommending revised land title types, and boundaries that match existing and proposed land uses.

\section{Housing Demand}

Housing need on remote Aboriginal communities is often dire. When preparing CLPs an average household size of 5 people is assumed as an accepted comfortable density. The present reality is often far from this ideal, with some households on communities housing more than 10 people In WA the primary developer of houses on Aboriginal 
